\title{
Antibacterial and anticancer activity of seaweeds and bacteria associated with their surface
}

\author{
Actividad anticancerígena y antibacteriana de macroalgas y bacterias asociadas a su superficie

\section{Luis J. Villarreal-Gómez ${ }^{1}$, Irma E. Soria-Mercado ${ }^{1}$, Graciela Guerra-Rivas $^{1}$ and Nahara E. Ayala-Sánchez ${ }^{2}$}

\author{
${ }^{1}$ Facultad de Ciencias Marinas, Universidad Autónoma de Baja California, Km 107 Carretera Tijuana- Ensenada, Ensenada, Baja \\ California, México.iesoria@uabc.edu.mx \\ ${ }^{2}$ Facultad de Ciencias, Universidad Autónoma de Baja California, Km 107 Carretera Tijuana- Ensenada, Ensenada, Baja California, \\ México
}

\begin{abstract}
Resumen.- Las bacterias y algas marinas son una fuente inagotable de compuestos químicos que permiten producir una amplia variedad de metabolitos secundarios bioactivos. Las bacterias marinas se han convertido en objetivo importante para la industria de la biotecnología debido a la alta cantidad de compuestos bioactivos descubierto recientemente a partir de ellas. El objetivo de este estudio fue evaluar la actividad anticancerígena y antibacteriana de extractos de las algas marinas Egregia menziesii, Codium fragile, Sargassum muticum, Endarachne binghamiae, Centroceras clavulatum y Laurencia pacifica recolectadas en Bahía Todos Santos, México. Se obtuvieron extractos orgánicos a partir de las algas libres de bacterias y de las bacterias asociadas a su superficie. Para probar la actividad antibacteriana se emplearon las cepas patógenas Staphylococcus aureus, Klebsiella pneumoniae, Proteus mirabilis y Pseudomonas aeruginosa y para la actividad anticancerígena, células de carcinoma colorectal HCT-116. De la superficie de las algas marinas se aislaron 35 cepas bacterianas que se identificaron molecularmente y pertenecían a los phyla Firmicutes, Proteobacteria, y Actinobacteria. Las cepas Cc51 aislada de Centroceras clavulatum, Sm36 aislada de Sargassum muticum, y Eb46 aislada de Endarachne binghamiae mostraron actividad anticancerígena con un $\mathrm{IC}_{50}$ de 6,492, 5,531 y 2,843 $\mu \mathrm{g} \mathrm{ml} \mathrm{m}^{-1}$ respectivamente. Asimismo, los extractos de las bacterias asociadas a las algas marinas inhibieron el crecimiento de la bacteria Gram negativa Proteus mirabilis. La actividad biológica observada en este estudio ofrece la oportunidad de un análisis químico posterior, tal como el aislamiento de los compuestos activos responsables, a fin de contribuir en el descubrimiento de nuevos fármacos.
\end{abstract}

Palabras clave: Compuestos bioactivos, bacterias simbiontes, algas bioactivas

\begin{abstract}
Marine algae and bacteria are an inexhaustible source of chemical compounds that produce a wide variety of biologically active secondary metabolites. Marine bacteria have become an important target for the biotechnology industry because of the large number of bioactive compounds recently discovered from them. The aim of this study was to evaluate the antibacterial and anticancer activities of extracts from the seaweeds Egregia menziesii, Codium fragile, Sargassum muticum, Endarachne binghamiae, Centroceras clavulatum and Laurencia pacifica collected from Todos Santos Bay, México. Organic extracts were obtained from bacteria-free algae and from surface-associated bacteria. Pathogen strains of Staphylococcus aureus, Klebsiella pneumoniae, Proteus mirabilis, and Pseudomonas aeruginosa were used to test antibacterial activity and HCT-116 colon cancer cells for anticancer activity. Thirty-five bacterial strains were isolated from the surface of seaweeds and molecular identified as belonging to the phyla Firmicutes, Proteobacteria and Actinobacteria by $16 \mathrm{~S}$ rDNA sequencing. The strains Cc51 isolated from Centroceras clavulatum, Sm36 isolated from Sargassum muticum, and Eb46 isolated from Endarachne binghamiae showed anticancer activity, with $\mathrm{IC}_{50}$ values of $6.492,5.531$, and $2.843 \mu \mathrm{g} \mathrm{ml}^{-1}$ respectively. Likewise, the extracts from the seaweed-associated bacteria inhibited the growth of the Gram negative bacterium Proteus mirabilis. The biological activity observed in this study offers opportunities for further chemical analyses, such as the isolation of the active compounds responsible for this activity, in order to contribute to the discovery of new drugs.
\end{abstract}

Key words: Bioactive compounds, symbiotic bacteria, bioactive algae

\section{INTRODUCTION}

Natural products are a major resource for drug development. A large number of plants, microbes, and marine animals have been examined for bioactive secondary metabolites (Firakova et al. 2007). Marine algae such as harbor endophytes, like their terrestrial counterparts, are a potential source of new secondary metabolites (Strobel et al. 2004). Despite this, the number of seaweed species studied and identified corresponds to only $2 \%$ of the 150,000 known 
species worldwide (Harvey et al. 1988). From the species identified, approximately two thousand chemical compounds have been characterized (Gonzalez \& Silva 2001). Bacteria are often found on the surface of many species of marine algae collected from natural habitats. These bacterial strains may be taken from the sea along with the algal cells, or may be found as a result of contamination in algal cultures (Jasti et al. 2005). Mixed bacterial populations observed on industrial crops and in natural ocean algal aggregations show that they use organic substances secreted by algal cells whether they are alive or dead. Nevertheless it has been noted that many algae present higher growth in the presence of bacteria than in their absence.

Several algal species need specific vitamins for their growth and bacteria may be partly responsible for the production of these substances. In addition, some seaweeds are capable of synthesizing antiviral, antibacterial, and/ or antifungal compounds against several pathogens, and bacteria found on algae are believed be the producers of these active compounds (Deig et al. 1974, Richards et al. 1978, Caccamese \& Azzolina 1979, Selvaraj et al. 1989, Bhakuni et al. 1990, Pérez et al. 1990, Ballesteros et al. 1992, Bhakuni et al. 1992, Jasti et al. 2005). The production of bioactive metabolites is considered to be a response to ecological pressures such as competition, predation deterrence, and reproduction. Such chemicals are often common in sessile eukaryotic organisms like marine sponges and corals, seaweeds, and terrestrial plants (Rosenthal \& Janzen 1979, Hay \& Fenical 1988, Pawlik 1993).

Since the late 1980 s, more than 50,000 natural products have been discovered from marine microorganisms. More than 10,000 had biological activity; among them, 8,000 had antibiotic and antitumor activities (Betina 1983, Berdy 1989). Marine bacteria often produce anticancer and antibacterial substances as a means of maintaining relationships between epiphytic micro-environments, inhibiting competing organisms and microbial pathogens (Avendaño-Herrera et al. 2005).

Some species of microorganisms show host specificity and specific antagonist activity against others; this specificity involves complex biochemical interactions between plants and microorganisms. Information is available that can provide direction in the selection of the type of organisms associated with medicinal plants when searching for new natural products (Strobel 2003). Microorganisms associated with plants produce necessary enzymes for colonization and like a symbiotic relation most of these microorganisms are able to use (at least in vitro) the cellular components of the plant (Sieber et al. 1991, Leuchtmann et al. 1992). Endophytic microorganisms are considered an outstanding source of bioactive natural products because many of them occupy literally millions of unique biological niches (higher plants) in many unusual environments. Thus, it would appear that a myriad of bio-typical factors associated with plants should be considered in the selection of a plant for study. It could be that these factors determine which microbes are present on plants as well as the biological activity of the products associated with these organisms. Despite the growing interest in chemical synthesis, natural bioactive products have a great impact on human health and are still out there waiting to be discovered and developed.

The objective of this study was to evaluate the antibacterial and anticancer activities of the organic extracts from six marine algae collected from Todos Santos Bay, Baja California, México, as well as the surface-associated bacteria.

\section{Material AND Methods}

\section{SAMPle COLlection}

The seaweeds Egregia menziesii (Turner) Areschoug $(E m)$, Codium fragile (Suringar) Hariot (Cf), Sargassum muticum (Yendo) Fensholt (Sm), Endarachne binghamiae (Petalonia binghamiae) (J. Agardh) Vinogradova (Eb), Centroceras clavulatum (Agardh) Montagne $(C c)$, and Laurencia pacifica Kylin $(L p)$ were collected by hand at low tide in the coastal area off the Autonomous University of Baja California (UABC) (31 $\left.511^{\prime} \mathrm{N} ; 116^{\circ} 40^{\prime} \mathrm{W}\right)$, Ensenada, BC, México. Collected samples (100 g) were transferred in zip-lock bags on ice. The algal surface was washed with fresh water, and a bacterial sample was taken from the surface with a sterile swab. Once the sample had been taken, the algal surface was rinsed again with sterile fresh water, dried with sterile paper, and stored in a sterile flask.

\section{ISOLATION OF BACTERIAL STRAINS}

A sterile swab was used to rub the seaweed surface and inoculating the removed bacteria on marine agar and marine broth (Difco) isolation plates. The inoculated plates were incubated for $24-48 \mathrm{~h}$ at $25^{\circ} \mathrm{C}$ until colonies were observed. Bacterial strains were purified through the third generation. Gram stain was used for initial bacterium classification; after staining the bacteria were stored in glycerol $\left(-70^{\circ} \mathrm{C}\right)$. 


\section{Purification of total DNA}

Pure bacterial strains were cultured in marine broth at $25^{\circ} \mathrm{C}$, and the total genomic DNA of each strain was extracted using the DNeasy Blood and Tissue Kit (Cat. No. 69506) according to the manufacturer's protocol (Qiagen Inc., CA, USA).

\section{Amplification of the 16S ribosomal DNA gene}

$16 \mathrm{~S}$ ribosomal DNA gene amplification was performed using PCR with the universal forward primer 27F (5'-AGAGTTTGATCMTGGCTCAG-3'; Galkiewicz \& Kellogg 2008) and reverse primer 1387R (5'-GGGCGGWGTGTACAAGGC-3'; Marchesi et al. 1998), using the following program: $5 \mathrm{~min}$ at $95^{\circ} \mathrm{C}, 1 \mathrm{~min}$ at $94^{\circ} \mathrm{C}, 1 \mathrm{~min}$ at $63^{\circ} \mathrm{C}, 1 \mathrm{~min}$ at $72^{\circ} \mathrm{C}$ for 35 cycles, $7 \mathrm{~min}$ at $72^{\circ} \mathrm{C}$ and held at $4^{\circ} \mathrm{C}$.

\section{SEQuencing}

The purified PCR products were commercially sequenced (Rebecca and John Moore Cancer Center Sequencing Facilities) using the universal primer 27F.

\section{Phylogenic analysis}

Sequences were analyzed using the Basic Local Alignment Search Tool (BLAST, Altschul et al. 1990) for preliminary species identification. The sequences were initially aligned using the ClustalX program (Staley \& Ta 1985), and then manually aligned in Bioedit (Hall \& Brown 2001) using a segment of 623 base pairs to construct a neighbor-joining tree. A phylogenic tree was constructed by a bootstrap test of 1000 replications, using the MEGA4 program (Tamura et al. 2007).

\section{GrowTH CURVES AND CRUDE BACTERIAL EXTRACTS}

Pure bacterial strains stored in glycerol were selected at a time for growth and incubated in a water bath $(250 \mathrm{rpm})$ at $30^{\circ} \mathrm{C}$. Cultures were left to grow for 2 to 4 days until reaching the exponential growth phase for each strain. Subsequently $20 \mathrm{~g} \mathrm{l}^{-1}$ of Amberlite XAD7 resin were added by stirring for $2 \mathrm{~h}$, and then filtered through gauze and finally through Whatman Grade 802 filter paper (12.5 $\mathrm{cm}$ diameter). The solids were extracted exhaustively with acetone using $12.5 \mathrm{ml} \mathrm{g}^{-1}$ of resin. Finally, crude acetone extracts were concentrated by distillation at reduced pressure (Buchi model 461 with a CVC2 vacuum pump). Each extract was given a code consisting of a capital letter and a lower-case letter, corresponding to the genus and species, respectively, of the alga from where the bacteria were isolated, followed by a sequential number for each bacterial strain. For example, Em 1 refers to Egregia menziesii, bacterium 1; Cc6 to Centrocera clavulatum, bacterium 6; and Lp2 to Laurencia pacifica, bacterium 2.

\section{Preparation of algal extracts}

The clean algae stored in sterile flasks were covered with a mixture of methanol and dichloromethane (7:3) and stored for 2 weeks at room temperature. Subsequently, the extract was filtered and concentrated by distillation under reduced pressure.

\section{Cytotoxic ACTIVITy}

The algal and bacterial extracts were each tested against HCT-116 colon cancer cells (10 $\mathrm{mg} \mathrm{ml}^{-1}$ in DMSO), obtaining medium inhibitory concentration $\left(\mathrm{IC}_{50}\right)$ values in $\mu \mathrm{g} \mathrm{ml}^{-1}$, using a dilution method in a 96-well plate. After $72 \mathrm{~h}$ incubation, absorbance was read at $490 \mathrm{~nm}$. DMSO was used as negative control and etoposide as positive control, both in the same concentrations as the compounds.

\section{ANTIBACTERIAL ACTIVITY}

The algal and bacterial extracts were tested against the pathogen bacteria Staphylococcus aureus (ATCC25923), Klebsiella pneumoniae (ATCC 13883), Proteus mirabilis (ATCC 35659), and Pseudomonas aeruginosa (ATCC 27853) at a concentration of $10 \mathrm{mg} \mathrm{ml}^{-1}$ in DMSO. The percentage of cell survival was obtained using a dilution method during $12 \mathrm{~h}$ incubation at $37^{\circ} \mathrm{C}$. Absorbance was read at $600 \mathrm{~nm}$, using DMSO as negative control and vancomycin as positive control.

\section{Results}

\section{IDENTIFICATION OF BACTERIAL STRAINS}

From the six species of marine algae collected, 35 bacterial strains were isolated. After Gram stain identification, 16 were classified as Gram positive and 19 as Gram negative.

Analysis of $16 \mathrm{~S}$ rDNA sequences showed that only 33 bacteria could be classified within three main phyla (Fig. 1): Actinobacteria (Cf2, Eb3, Sm2, Em6, Cc5, and Cc1; Gram positive), Proteobacteria (Cc3, Sm7, Cc7, Sm5, Cf4, Lp5, $L p 2, E b 6, E b 7$, and Cf5; Gram negative), and Firmicutes (Cf1, Eb2, Cc4, Em2, Em5, Lp3, Cf3, Eb5, Sm6, Cf6, Cc2, $S m 4, E b 1, C c 6, E m 4, E m 1$, and $E b 4$; Gram positive).

Based on the genetic results, the phylogenic tree could be divided into two main clusters: Gram positive and negative 


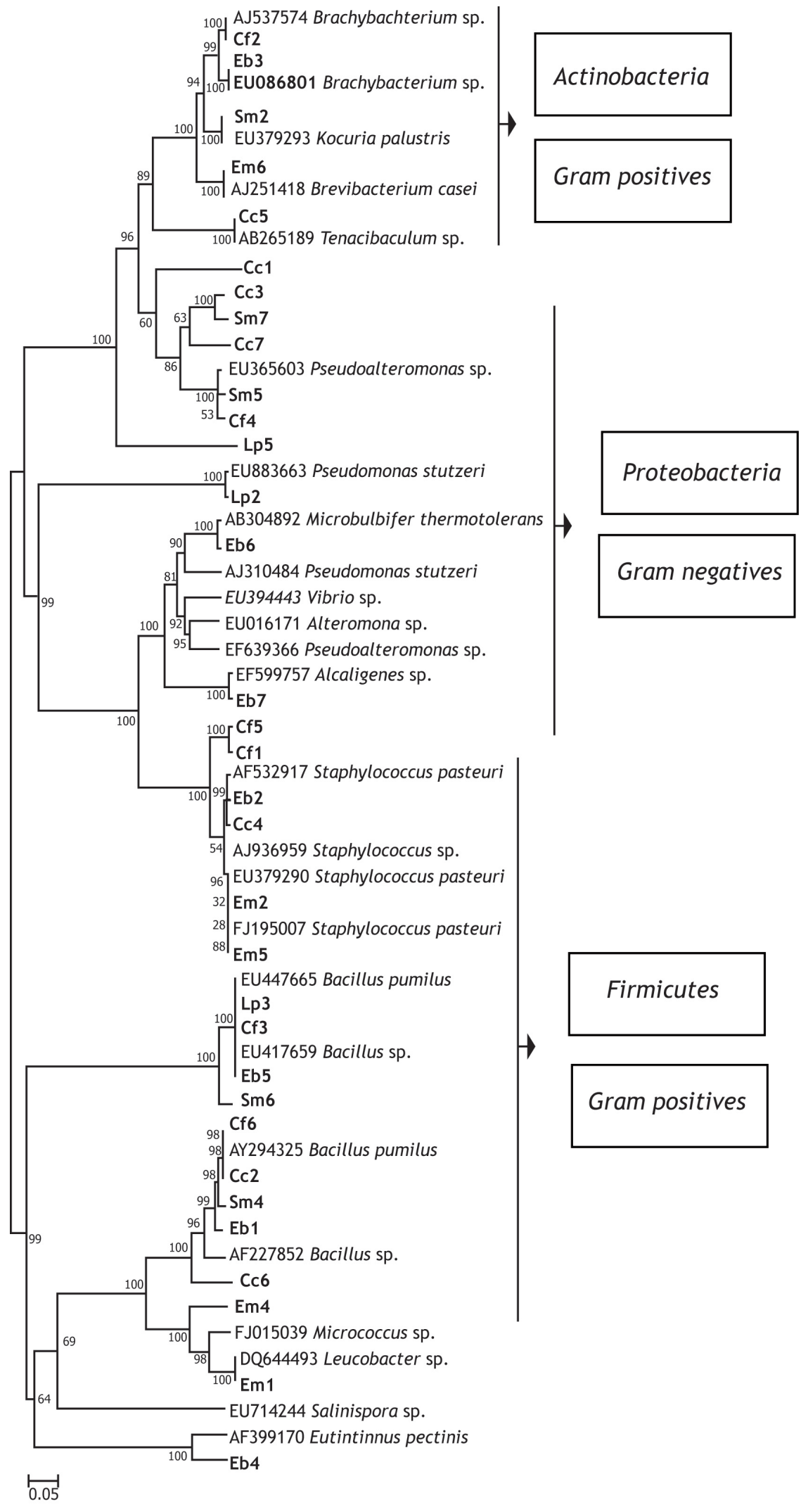

Figure 1. Phylogram of the evolutionary relationships of 58 taxa of marine bacteria with sequenced clones using universal primers $27 \mathrm{~F}$ and $1387 \mathrm{R}$ for marine samples. The evolutionary history was assessed using the method of construction described by neighborjoining (Saitou \& Nei 1987), based on a total of 625 base pairs in MEGA4 (Tamura et al. 2007) / Filograma de las relaciones evolutivas de 58 taxas de bacterias marinas con las clonas secuenciadas usando los cebadores universales de bacterias $27 \mathrm{~F}$ y $1387 \mathrm{R}$ para muestras marinas. La historia evolutiva fue determinada usando el método del vecino más cercano (Saitou \& Nei 1987) con un total de 625 pares de bases en MEGA4 (Tamura et al. 2007) 
bacteria. No particular association was found between any algal species and a specific type of bacteria. As shown in Fig. 1 , all strains belonging to each different group of bacteria are evenly distributed with no species-relation pattern.

\section{Biological ACTIVITY}

The biological activity observed for the different organic extracts tested showed that the strains $E m 6, C c 3$, and Cc5 (isolated from E. menziesii and C. clavulatum) had low activity against colorn cancer cells (HCT-116), with $\mathrm{IC}_{50}$ values of $58.0,101.6$, and $56.7 \mu \mathrm{g} \mathrm{ml}^{-1}$, respectively. The most cytotoxic strains were $C c 1$ (isolated from $C$. clavulatum) and $\mathrm{Sm} 6$ (isolated from S.muticum), with $\mathrm{IC}_{50}$ values of 6.4 and $5.5 \mu \mathrm{g} \mathrm{ml}^{-1}$, respectively, while strain $E b 6$ (isolated from E. binghamiae) showed the highest anticancer activity, with an $\mathrm{IC}_{50}$ value of $2.8 \mu \mathrm{g} \mathrm{ml}^{-1}$ (Table 1).

Fourteen bacterial strains and five algae (all except $E$. menziesii) showed antibacterial activity against Proteus mirabilis. None of the extracts from marine algae and bacteria were active against $S$. aureus and P. aeruginosa. Extracts of strains $E m 2, C f 1, C f 6, S m 2, S m 6, E b 4, E b 5$, $E b 6, C c 1, C c 2, C c 3, C c 7, L p 2$, and $L p 3$ presented weak antimicrobial activity against $P$. mirabilis, and bacterial growth greater than $50 \%$ was observed as shown by the $\mathrm{LD}_{50}$ values (Table 1). Likewise, extracts of the seaweeds $C f, S m, E b, C c$, and $L p$ showed $\mathrm{LD}_{50}$ values of 140.1, 140.1, $178.5,181.9$, and $107.1 \mu \mathrm{g} \mathrm{ml}^{-1}$, respectively. The bacterium $K$. pneumonia showed low sensitivity against the extracts tested, and only two strains of E. menziesii, Em 1 and Em4, showed antibacterial activity, with $\mathrm{LD}_{50}$ values of 211.5 and $203.0 \mu \mathrm{g} \mathrm{ml}^{-1}$, respectively (Table 1 ).

\section{Discussion}

As a result of the Gram staining of the 35 bacteria analyzed in this study, 16 were classified as Gram positive and 19 as Gram negative. Previous bacterioplankton studies have shown that the majority of marine bacteria are Gram negative; however, recent studies on marine sediment microbial communities have found evidence that most bacteria from this environment appear to be Gram positive (Gontang et al. 2007). Strains isolated from the surface of Laurencia pacifica showed a trend towards Gram negative bacteria, but no trend was observed for the remaining seaweeds regarding Gram positive and Gram negative abundance. The Gram classification could be an interesting tool if the differences between the structure and chemical composition of the two main groups of bacteria are considered. These group-specific chemical characteristics could allow the interaction between bacteria and algae.
The abundance trend of specific bacterial groups in the marine algae observed in this study may be explained by these chemical interactions. Gallardo et al. (2004) found a predominance of Gram negative bacteria belonging to the following genera: Vibrio (20\%), Escherichia coli inactive $(18 \%)$, Flavobacterium (11\%), Flexibacter (9\%), Moraxella (9\%), Pseudomonas (9\%), Aeromonas (2\%), Acinetobacter (2\%), Cotophaga (2\%), Photobacterium (2\%) and Alteromonas (2\%). Gram positive bacteria (Staphylococcus) were also found in the seaweed Monostroma undulatum.

Of the 35 bacterial strains isolated from the 6 seaweed, it was possible to phylogenetically identify 33 , located within the phyla Firmicutes, Proteobacteria and Actinobacteria (the last is considered excellent producers of bioactive secondary metabolites) (Jensen et al. 2005, Macherla et al. 2005). The distribution of the 15 bacterial species identified showed no tendency toward the colonization of specific algae. However, it was noted that some bacteria grew only in very particular algae; for example, Leucobacter sp. was observed only in Egregia menziesii. This bacteria class member of the Actinobacteria, were found linked to the nematode Caenorhabditis elegans (Muir \& Tan 2008).

Industrial applications have been reported for some of the bacterial species found in this study. For example, Alcaligenes (Eb7), found exclusively on the alga Endarachne binghamiae, has been used for the industrial production of non-standard amino acids (Madigan et al. 2005). Tenacibaculum (Cc5), found only on the alga Centroceras clavulatum, has been found associated with sponges and seaweed producers of secondary metabolites in the Palau Islands (Suzuki et al. 2001). The strain Sm2, identified as Kocuria palustris, was exclusively found on Sargassum muticum; this alga is considered an invasive species in many countries, but the species of bacteria found on it (Kocuria) has industrial applications as the field gradient Organic (Kovacs et al. 1999). Finally, bacterial strains of the genus Alteromonas (Lp5) were found associated only with the alga Laurencia pacifica, usually isolated in seawater. The Proteobacteria species have industrial uses because they produce high molecular weight polysaccharides. These observations suggest that some bacteria can be industrially exploited.

Bacillus species proliferated on all algae, except Egregia menziesii. A total of 9 strains (26\%) of the 35 bacteria studied belonged to this species that is usually found in soil, seawater, and rivers. It has been reported that Bacillus brevis, B. cereus, B. circulans, B. laterosporus, B. licheniformis, B. polymyxa, B. pumilus, and B. subtilis produce antibiotics (Madigan et al. 2005). All entries are 
Table 1. Anticancer and antibacterial activity values of seaweeds extracts: Egregia menziesii (Em), Codium fragile $(C f)$, Sargassum muticum $(S m)$, Endarachne binghamiae $(E b)$, Centroceras clavulatum $(C c)$ and Laurencia pacifica $(L p)$ and the extracts of the bacterial strains isolated from each algae, labeled with the abbreviation of the algae name and progressive numbers / Actividad anticancerígena y antibacteriana de los extractos de las algas: Egregia menziesii $(E m)$, Codium fragile (Cf), Sargassum muticum $(\mathrm{Sm})$, Endarachne binghamiae $(E b)$, Centroceras clavulatum $(C c)$ y Laurencia pacifica $(L p)$, y de los extractos de las bacterias aisladas de cada una de las algas, representadas con la abreviatura del nombre del alga y números progresivos

\begin{tabular}{|c|c|c|c|}
\hline Seaweed and bacteria strains & $\begin{array}{c}\text { HCT-116 } \\
\text { Colorectal } \\
\text { cancer cells } \\
\mathrm{IC}_{50}\left(\mu \mathrm{g} \mathrm{ml}^{-1}\right)\end{array}$ & $\begin{array}{c}\text { Klebsiella } \\
\text { pneumoniae } \\
\text { MIC }\left(\mu \mathrm{g} \mathrm{ml}^{-1}\right)\end{array}$ & $\begin{array}{c}\text { Proteus } \\
\text { mirabilis } \\
\mathrm{MIC}\left(\mu \mathrm{g} \mathrm{ml}^{-1}\right)\end{array}$ \\
\hline Egregia menziesii & * & * & * \\
\hline$E m 1$ & $*$ & 211.5 & $*$ \\
\hline$E m 2$ & $*$ & $*$ & 212.3 \\
\hline$E m 4$ & $*$ & 203.0 & $*$ \\
\hline $\operatorname{Em} 5$ & $*$ & $*$ & $*$ \\
\hline $\operatorname{Em} 6$ & 58.0 & $*$ & $*$ \\
\hline Codium fragile & $*$ & * & 140.1 \\
\hline$C f 1$ & $*$ & * & 196.0 \\
\hline$C f 2$ & $*$ & $*$ & $*$ \\
\hline$C f 3$ & $*$ & $*$ & $*$ \\
\hline$C f 4$ & $*$ & $*$ & $*$ \\
\hline$C f 5$ & $*$ & $*$ & $*$ \\
\hline$C f 6$ & $*$ & $*$ & 213.9 \\
\hline Sargassum muticum & $*$ & $*$ & 140.1 \\
\hline$S m 2$ & $*$ & $*$ & 165.7 \\
\hline $\operatorname{Sm} 4$ & * & * & $*$ \\
\hline$S m 5$ & $*$ & $*$ & $*$ \\
\hline $\operatorname{Sm} 6$ & 5.5 & $*$ & 174.0 \\
\hline $\operatorname{Sm} 7$ & $*$ & $*$ & $*$ \\
\hline Endarachne binghamiae & $*$ & * & 178.5 \\
\hline$E b 1$ & $*$ & $*$ & $*$ \\
\hline$E b 2$ & $*$ & $*$ & $*$ \\
\hline$E b 3$ & $*$ & $*$ & $*$ \\
\hline$E b 4$ & $*$ & * & 188.1 \\
\hline Eb5 & * & * & 209.7 \\
\hline$E b 6$ & 2.8 & $*$ & 178.9 \\
\hline$E b 7$ & $*$ & $*$ & $*$ \\
\hline Centroceras clavulatum & $*$ & $*$ & 181.9 \\
\hline$C c 1$ & 6.4 & $*$ & 180.5 \\
\hline$C c 2$ & $*$ & * & 217.1 \\
\hline$C c 3$ & 101.6 & $*$ & 153.1 \\
\hline$C c 4$ & $*$ & * & $*$ \\
\hline$C c 5$ & 56.7 & $*$ & $*$ \\
\hline Cc6 & $*$ & $*$ & $*$ \\
\hline$C c 7$ & $*$ & $*$ & 159.1 \\
\hline Laurencia pacifica & $*$ & * & 107.1 \\
\hline$L p 2$ & $*$ & $*$ & 185.4 \\
\hline$L p 3$ & $*$ & * & 288.1 \\
\hline$L p 4$ & $*$ & $*$ & $*$ \\
\hline Lp5 & * & * & $*$ \\
\hline Lp6 & $*$ & $*$ & $*$ \\
\hline
\end{tabular}

$\mathrm{IC}_{50}:$ Medium inhibitory concentration

MIC : Minimum inhibitory concentration

* : No significant activity 
important to mention, since several of the bacterial strains found are close to those used in the industry. Therefore, it is necessary to study the chemical interactions of algae and bacteria for a better understanding of the production process of secondary metabolites.

The biological activity results of this study revealed that a few strains have anticancer activity: $E b 6$, with an $\mathrm{IC}_{50}$ value of $2.8 \mu \mathrm{g} \mathrm{ml}^{-1}$, showed a sequence similarity of $98.03 \%$ to Microbulbifer thermotolerans, and Cc1, with an $\mathrm{IC}_{50}$ value of $6.4 \mu \mathrm{g} \mathrm{ml}^{-1}$, showing a sequence similarity of $79.02 \%$ to Pseudoalteromonas sp. In recent studies, these two species of Proteobacteria were found in bioflms in marine areas and were found to produce chemical compounds to protect themselves from predators. One of these compounds is tholacein, an alkaloid thatwhas been shown to be synthesized predominantly in biofilms, the compound in $\mathrm{nM}$ concentrations inhibits protozoan cells and induce programmed cell death in eukaryotic cells. These biofilm-producing bacterial strains secrete chemicals that contribute to the specific defense for a successful survival in several environments and provide an ecological and evolutionary context for the discovery of bacterial metabolites to eukaryotic cells (Matz et al. 2008).

Another strain showing anticancer activity was $\operatorname{Sm} 6$, with an $\mathrm{IC}_{50}$ value of $5.5 \mu \mathrm{g} \mathrm{ml}^{-1}$ and a sequence similarity of $99.87 \%$ to Bacillus. Although this type of bacterium can be found in almost any substrate, it can be suggested that because of its association with Sargassum muticum, it seems to have acquired the ability to synthesize a compound able to inhibit colon cancer cells (HCT-116). Sargassum muticum has been found to show low antibacterial activity against some species of marine algae (Hellio et al. 2001).

The bacterial strains and marine algae showed no antibacterial activity against the bacteria Staphylococcus aureus and Pseudomonas aeruginosa. These results indicate that certain species have selective response mechanisms, as suggested by Matz et al. (2008). It is therefore possible that the algae used in this study, which were collected from the same coastal area, share similar defense mechanisms, creating an ecological and biotechnological interest in this natural marine natural product.

Finally, our findings indicate that the organisms, collected from the same area, show similar antibacterial activity against Proteus mirabilis. This bacterium is detrimental to human health causing wound infections, septicemia, pneumonia, and kidney stones, as well as other diseases. Despite the fact that $P$. mirabilis is susceptible to many antibiotics such as tetracycline, $10 \%$ to $20 \%$ of the strains are resistant to ampicillin and first-generation cephalosporins, which is an interesting finding for ecology and bioactive chemical compounds.

\section{ACKNOWLedgments}

The authors thank A. Prieto-Davo and P.R Jensen (CMBB, Scripps Institution of Oceanography, University of California at San Diego) for their collaboration, A. Licea for allowing the performance of the bioassays at CICESE, M. Ritchie for facilitating the bacterial pathogens used, and R. Aguilar ( $\dagger$ ) for assistance in the identification of seaweeds.

\section{LITERATURE CITED}

Altschul SF, W Gish, W Miller, EW Myers \& DJ Lipman. 1990. Basic local alignment search tool. Journal of Molecular Biology 215(3): 403-410.

Avendaño-Herrera R, M Lody \& CE Riquelme. 2005. Producción de substancias inhibitorias entre bacterias de biopelículas en substratos marinos. Revista de Biología Marina y Oceanografía 40(2): 117-125.

Ballesteros JJ, A Guzman \& R Cortadellas. 1992. Urinary infection and stone formation as complications of GilVernet's antireflux procedure. International Urology and Nephrology 24(6): 613-616.

Berdy J. 1989. The discovery of new bioactive microbial metabolites: screening and identification. In: Bushell ME \& U Grafe (eds). Bioactive metabolites from microorganisms. Progress in Industrial Microbiology 27: 3-25.

Betina V. 1983. The chemistry and biology of antibiotics, 590 pp. Elsevier, Amsterdam.

Bhakuni DS, AK Goel, S Jain, BN Mehrotra \& RC Srimal. 1990. Screening of Indian plants for biological activity: Part XIV. Indian Journal Experimental Biology 28(7): 619637.

Bhakuni DS, BN Dhawan, HS Garg, AK Goel, BN Mehrotra, RC Srimal \& MN Srivastava. 1992. Bioactivity of marine organisms: Part VI-Screening of some marine flora from Indian coasts. Indian Journal of Experimental Biology 30(6): 512-517.

Caccamase S \& R Azzolina. 1979. Screening for antimicrobial activities in marine algae from eastern Sicily. Planta Medica 37(4): 333-339.

Deig EF, DW Ehresmann, MT Hatch \& DJ Riedlinger. 1974. Inhibition of herpesvirus replication by marine algae extracts. Antimicrobial Agents and Chemotherapy 6(4): 524-525.

Firakova S, M Sturdikova \& M Muckova. 2007. Bioactive secondary metabolites produced by microorganisms associated with plants. Biologia 62(3): 251-257. 
Galkiewicz JP \& CA Kellogg. 2008. Cross-kingdom amplification using Bacteria-specific primers: Complications for studies of coral microbial ecology. Applied and Environmental Microbiology 74(24): 78287831.

Gallardo A, S Risso, M Fajardo \& B Estevao. 2004. Caracterización de poblaciones microbianas presentes en la macroalga comestible, Monostroma undulatum Wittrock. Archivos Latinoamericanos Nutrición 54(3): 337-345.

Gontang EA, W Fenical \& PR Jensen. 2007. Phylogenetic diversity of gram-positive bacteria cultured from marine sediments. Applied and Environmental Microbiology 73: 3273-3282.

González F \& M Silva. 2001. Biodiversidad química de macroalgas marinas. In: Alveal K \& T Antezana (eds). Sustentabilidad de la biodiversidad, un problema actual. Bases científico-técnicas, teorizaciones y proyecciones, pp. 415-496. Universidad de Concepción, Concepción.

Hall TA \& JW Brown. 2001. The ribonuclease P family. Methods in Enzymology 341: 56-77.

Harvey SC, J Luo \& R Lavery. 1988. DNA stem-loop structures in oligopurine-oligopyrimidine triplexes. Nucleic Acids Research 16(24): 11795-11809.

Hay ME \& W Fenical. 1988. Marine plant-herbivore interactions: the ecology of chemical defense. Annual Review of Ecology Systematics 19: 111-145.

Hellio C, D De La Broise, L Dufossé, Y Le Gal \& N Bourgougnon. 2001. Inhibition of marine bacteria by extracts of macroalgae: potential use for environmentally friendly antifouling paints. Marine Environmental Research 52(3): 231-247.

Jasti S, M Sieracki, N Poulton, MW Giewat \& JN RooneyVarga. 2005. Phylogenetic diversity and specificity of bacteria closely associated with Alexandrium spp. and other phytoplankton. Applied and Environmental Microbiology 71(7): 3483-3494.

Jensen PR, T Mincer, PG Williams \& W Fenical. 2005. Marine actinomycete diversity and natural product discovery. Antonie Van Leeuwenhoek 87(1): 43-48.

Kovacs G, J Burghardt, S Pradella, P Schumann, E Stackebrant \& K Marialigeti. 1999. Kocuria palustris $s p$. nov. and Kocuria rhizophila sp. nov., isolated from the rhizoplane of the narrow-leaved cattail (Typha angustifolia). International Journal of Systematic Bacteriology 49: 167173.

Leuchtmann A, O Petrini, LE Petrini \& GC Carroll. 1992. Isozyme polymorphism in six endophytic Phyllosticta species. Mycological Research 96(4): 287-294.

Macherla VR, SS Mitchell, RR Manam, KA Reed, TH Chao, B Nicholson, G Deyanat-Yazdi, B Mai, PR Jensen, W
Fenical, STC Neuteboom, KS Lam, MA Palladino \& BCM Potts. 2005. Structure-activity relationship studies of Salinosporamide A (NPI-0052), a novel marine derived proteasome inhibitor. Journal of Medicinal Chemistry 48(11): 3684-3687.

Madigan M, J Martinko \& J Parker. 2005. Brock, Biology of microorganisms, 1088 pp. Prentice Hall, New York.

Marchesi JR, T Sato, AJ Weightman, TA Martin, JC Fry, SJ Hiom \& WG Wade. 1998. Design and evaluation of useful bacterium-specific PCR Primers that amplify genes coding for bacterial 16S rRNA. Applied and Enviromental Microbiology 64(2): 795-799.

Matz C, JS Webb, PJ Schupp, SY Phang, A Penesyan, S Egan, P Steinbert \& S Kjelleberg. 2008. Marine Biofilm bacteria evade eukaryotic predation by targeted chemical defense. PLoS ONE 3(7), e2744 <doi:10.1371/journal. pone.0002744>

Muir RE \& M Tan. 2008. Virulence of Leucobacter chromiireducens subsp. solipictus to Caenorhabditis elegans: Characterization of a novel host-pathogen interaction. Applied and Environmental Microbiology 74(13): 4185-4198.

Pawlik JR. 1993. Marine invertebrate chemical defenses. Chemical Reviews 93: 1911-1922.

Pérez JL, A Pulido, F Pantozzi \& R Martin. 1990. Butyrate esterase (4-methylumbelliferyl butyrate) spot test, a simple method for immediate identification of Moraxella (Branhamella) catarrhalis. Journal of Clinical Microbiology 28(10): 2347-2348.

Richards H, N Datta, WJ Sojka \& C Wray. 1978. Trimethoprim-resistance plasmids and transposons in Salmonella. The Lacet 312(8101): 1194-1195.

Rosenthal GA \& DH Janzen. 1979. Herbivores: Their interaction with secondary plant metabolites, $718 \mathrm{pp}$. Academic Press, Orlando.

Saitou N \& M Nei. 1987. The neighbor-joining method: a new method for reconstructing phylogenetic trees. Molecular Biology and Evolution 4(4): 406-425.

Selvaraj R, S Manivasaham, A Purushothaman \& A Subramianian. 1989. Preliminary investigation on antibacterial activity of some marine diatoms. Indian Journal of Medical Research 89: 198-200.

Sieber TN, F Sieber-Canavesi \& CE Dorwoth. 1991. Endophytic fungi of red alder (Alnus rubra) leaves and twigs in British Columbia. Canadian Journal of Botany 69: 407-411.

Staley J \& A Konopka. 1985. Measurement of in situ activities of nonphotosynthetic microorganisms in aquatic and terrestrial habitats. Annual Reviews in Microbiology 39: 321-346. 
Strobel G. 2003. Endophytes as sources of bioactive products. Microbes and Infection 5(6): 535-544.

Strobel G, B Daisy, U Castillo \& J Harper. 2004. Natural products from endophytic microorganisms. Journal of Natural Products 67(2): 257-268.

Suzuki M, Y Nakagawa, S Harayama \& S Yamamoto. 2001. Phylogenetic analysis and taxonomic study of marine Cytophaga-like bacteria: proposal for Tenacibaculum gen. nov. with Tenacibaculum maritimum comb. nov. and Tenacibaculum ovolyticum comb. nov., and description of Tenacibaculum mesophilum sp. nov. and Tenacibaculum amylolyticum sp. nov. International Journal Systematic Evolutionary Microbiology 51: 1639-1652.

Tamura K, J Dudley, M Nei \& S Kumar. 2007. MEGA4: Molecular evolutionary genetics analysis (MEGA) software version 4.0. Molecular Biology and Evolution 24(8): 1596-1599.

Zhuang W, J Tay, A Maszenan, L Krumholz \& S Tay. 2003. Importance of Gram-positive naphthalene-degrading bacteria in oil-contaminated tropical marine sediments. Applied Microbiology 36(4): 251-257.

Recibido el 12 de noviembre de 2009 y aceptado el 7 de mayo de 2010 